\title{
TYPOLOGIZATION OF THE EFFECTS FROM THE INTRODUCTION AND USE OF INFORMATION AND COMMUNICATION TECHNOLOGIES AND THEIR CHARACTERISTICS
}

\author{
Tetiana Hushtan ${ }^{1}$, Svitlana Danylo²
}

\begin{abstract}
The subject of the study is to consider the impact of information and communication technologies (ICT) on the country's economic development that requires providing the systematic research of objective prerequisites for increasing ecological and economic efficiency of the introduction and use of ICT. The economic justification for the implementation of ICT taking into account the economic consequences of its impact on the environment is impossible without studying, systematizing economic and environmental effects from the use of ICT. Scientific studies of the economic problems of the implementation of ICT, in our opinion, should be deepened on the basis of the need to take into account the positive and negative economic consequences of their impact on the environment and therefore require further research in this direction. The purpose of the paper is to determine the impact of information and communication technologies on the country's ecological and economic development and to systematize the economic, social and environmental effects from the introduction and use of ICT. The dialectical method of scientific knowledge, method of analysis and synthesis, comparative method, method of data generalization are used in the paper. The paper outlines and describes the main directions of influence of information and communication technologies (ICT) on economic development of industry, on development of agriculture, on the sphere of transport and communication. The classification of the effects from the introduction and use of ICT is given, namely: by the life cycle of the product - the effects that arise at the stage of development, production, realization, consumption and disposal of the product; by recipients of influence - the effects that arise in enterprises, government bodies, which use ICT, households, which are consumers of ICT goods and services, and in the environment; by the form of manifestation - direct and indirect effects. ICT provide extensive opportunities for learning, promote the participation of citizens in public life, etc., but at the same time they can increase the unevenness of the economic development of the regions of the country due to the difference in access to ICT. The development of ICT provides a reduction in the material component of production and consumption, helping to reduce the resource intensity and ecological sustainability of economic processes, and improve the environmental situation.
\end{abstract}

Key words: information and communication technologies, market, effects, information, enterprises, investments, information society, business, ecology.

JEL Classification: $\mathrm{C} 42, \mathrm{O} 32$

\section{Introduction}

The intensive development of information technology in the modern world leads to the fact that information becomes crucial for economic, social and environmental progress. The development of information and communication technologies (ICT) in the information

Corresponding author:

${ }^{1}$ Uzhhorod Trade and Economic Institute

of Kyiv National University of Trade and Economic, Ukraine.

E-mail: hushtantetiana@gmail.com

ORCID: https: //orcid.org/0000-0002-0299-0437

ResearcherID: https://publons.com/researcher/4506839/

${ }^{2}$ Uzhhorod Trade and Economic Institute

of Kyiv National University of Trade and Economic, Ukraine.

E-mail: kveta_utei@ukr.net

ORCID: https://orcid.org/0000-0003-3300-7172 society is becoming crucial for socio-ecological and economic development. There is a close connection between the level of ICT development and the socioecological and economic development of the state.

The transition to the information society and the need to take into account the results of the impact of 
information and communication technologies on the country's economic development requires providing the systematic research of objective prerequisites for increasing ecological and economic efficiency of the introduction and use of ICT. The economic justification for the implementation of ICT taking into account the economic consequences of its impact on the environment is impossible without studying, systematizing not only economic but also environmental effects from the use of ICT. The theory and practice of assessing the socio-eco-economic efficiency of ICT implementation and use will require further improvement.

Information and communication technologies are a potentially powerful mechanism for transforming public life and growing the world economy. ICTs are also able to expand the range of social projects and increase their effectiveness. Thus, thanks to the use of ICT, the state has already received significant benefits in the field of health, education and environmental protection. Improving the characteristics of ICT and the implementation of new functionalities actually play the role of an engine for large-scale changes in the economy.

Such changes are twofold: first, there are changes in the internal nature of the goods or services provided by ICTs, and second, as a means of seriously transforming the relationship between governments, companies, citizens and consumers. In this regard. among many other goals, one of the most important tasks of ICT is to support sustainable development. The concept of sustainable development emerged as a result of combining three main points of view on the development of society: economic, social, and environmental.

\section{Analysis of recent research and publications}

The works of both domestic and foreign scolars and scientists: O. Balatsky (Balatskiy, 1979), L. Varakin (Varakin, 2005), M. Zgurovskiy (Zgurovskiy, 2005), V. Ivanova (Ivanova, 2008), V. Inozemtsev (Inozemtsev, 2000), M. Castells (Castells, Hymanen, 2002), V. Kovalevskyi (Kovalevskyi, 2003), D. Lyon (Lyon, 1996), C. Nelson (Nelson, 1993), M. Makarova (Makarova, 2002), Ye. Khlobystov (Khlobystov, 2004), A. Chukhno (Chukhno, 2003) et al. are devoted to the study of the relationships between economic development and environmental processes, the problems of assessing the positive and negative economic, social, environmental effects from the introduction and use of ICT. In spite of the results obtained, scientific studies of the economic problems of the implementation of ICT, in our opinion, should be deepened on the basis of the need to take into account the positive and negative economic consequences of their impact on the environment and therefore require further research in this direction.
The purpose of the paper is to determine the impact of information and communication technologies on the country's ecological and economic development and to systematize the economic, social and environmental effects from the introduction and use of ICT.

\section{Introduction and use of information and communication technologies}

The intensive development of information technologies in the modern world leads to the fact that information becomes crucial for economic, social and environmental progress. The transition to the information society implies the implementation of systemic changes in the social, economic, political, legal, and cultural structure of society.

The development of information and communication technologies in the information society becomes crucial for socio-eco-economic development. There is a close link between the level of ICT development and the socioeco-economic development of the state. Information and communication technologies is a potentially powerful mechanism for transforming public life and the growth of the world economy. At a basic level, they help different institutions work more productively, thereby increasing their competitiveness and productivity. ICT are also able to expand the range for realization of social projects and improve their effectiveness. Thus, thanks to the use of ICT, the state has already benefited greatly from health, education and the environment (The role of modern information technologies in socio-economic development, 2005). Improving the characteristics of ICT and the implementation of new functional capabilities actually play the role of engine for realization of large-scale changes in the economy. Such changes are twofold: firstly, there are changes in the internal nature of goods or services provided through ICT, and secondly, as a means of a serious transformation of relations between governments, companies, citizens and consumers. In this regard, among many other goals, one of the most important tasks of ICT is to support sustainable development. The concept of sustainable development arose as a result of the unification of three main points of view on the development of society: economic, social and environmental. The economic, social and environmental spheres are equally important and interdependent. At the same time, economic sustainability means that economic growth takes place without the presentation of special requirements for the social sphere or for natural resources; the environmental sustainability means not only minimizing the impact on the natural environment, but also on the state of natural resources and preserving them for the future; social sustainability means improvement and, in no case, destruction of the achieved level of social equality (European Information Technology Observatory yearbook, 2002). 
The effective use of the benefits of ICT can be a driving force in achieving of sustainable development, which expresses the relationship between the economic, environmental and social spheres.

\subsection{Areas of influence of ICT on the economic development of industry}

The impact of ICT has its positive and negative manifestations in any area of the national economy. Consider the directions of the influence of ICT on the economic development of industry:

1) positive impact:

- increasing labor productivity;

- increasing market efficiency (as a result of obtaining access of enterprises to the global market of suppliers and consumers);

- reduction of expenses on account of management automation;

- the properties of virtual ICT goods (low marginal costs for copying, distributing and providing communications) reduce operating costs;

- an opportunity for enterprises to respond quickly on market development;

- increasing of efficiency of supply and production networks, reduction of stocks due to the use of systems "exactly on time";

- carrying out the Internet conferences, negotiations allow to reduce expenses for business trips;

- ICT market growth (new types of goods, entrepreneurial activity, employment growth);

- structural changes in the economy (an increase in the share of services);

- increasing the need for qualified ICT specialists;

- increasing the number of the Internet users, personal computers;

- the use of advanced technologies is more energy-efficient; - telework (for example, at home through the Internet), as well as Internet conferences, negotiations reduce the number of passengers, reducing emissions of harmful substances (including CO2) from vehicles;

- efficient management of supply systems reduces cargo transportation, reducing emissions of harmful substances (in particular, CO2) into the atmosphere; - increasing the efficiency of consumption of natural resources due to the dematerialization of goods, the use of efficient technologies and renewable energy sources;

2) negative impact:

- comparative advantages of using ICT in different regions may contribute to uneven distribution of economic benefits;

- at the initial stage of ICT implementation, significant investments and long waiting times are needed for their use;

- availability of costs related to the security of information systems, the risk of using the Internet (viruses, attacks, etc.);
- a reduction in the number of jobs due to automation of production processes;

- increasing the digital gap among the population within the country, between countries, regions, etc.;

- electricity consumption, even in standby mode;

- use of toxic substances in the production of ICT equipment;

- the problem of recycling waste for electronic devices, etc.

\subsection{Areas of influence of ICT on the development of agriculture}

Consider the directions of the impact of ICT on the development of agriculture:

1) positive direction:

- possibility of remote on-line monitoring and analysis of business processes using the Internet;

- possibility of rural communication development;

- use of global and local knowledge systems for farms;

- global positioning and dispatching of field technology,

etc.;

- increasing e-literacy among the rural population;

- the need for qualified ICT specialists;

- satisfaction of cultural needs, leisure activities of rural inhabitants;

- rational use of agricultural lands, natural resources, etc.;

2) negative direction:

- increasing economic inequality between rural and urban populations;

- increasing the digital gap between rural and urban areas;

- electricity consumption by ICT equipment.

\subsection{Areas of ICT impact on transport and communications}

In our opinion, the main areas of influence of ICT on the sphere of transport and communication are:

1) positive direction:

- an increase in the volume of freight by increasing the number of deliveries to "home";

- expanding travel opportunities through the use of mobile ICT;

- increasing the density of telephone lines;

- development of mobile communication, high-speed Internet access;

- opportunity to purchase travel documents, including international ones, at ticket offices throughout the country and with the help of the Internet;

- optimization of transportation using logistics systems;

- increasing the need for qualified ICT specialists;

- increasing the number of the Internet users, mobile communication;

- greater accessibility of international communication, etc.; 
2) negative direction:

- reduction of passenger traffic due to telework, Internet conferences, etc.;

- growth of losses of companies engaged in activities in the field of traditional means of communication (post, telegraph communication);

- reducing the number of jobs due to automation of process management;

- an increasing in the digital gap between the population within the country, between countries, regions, etc.;

- increasing cargo and passenger transportation, and, accordingly, $\mathrm{CO} 2$ emissions into the atmosphere, due to the growth of the level of "human mobility";

- increasing electricity consumption by ICT equipment, etc.

\subsection{Classification of economic, social and environmental impacts related to ICT implementation}

Most studies use the classification of economic, social and environmental effects associated with the implementation of ICT, where they are divided into three groups: first-order effects associated with the processes of development, production, operation and utilization of ICT equipment; second-order effects associated with the use of ICT; third-order effects, which are the combined effects of the massive use of ICT in the long run.

In Figure 1, a classification of effects from the introduction and use of ICT is provided.

According to the product life cycle, the effects divided on the effects of emerging at the stages of development, production, sale, consumption and disposal; according to the recipients of influence - the effects in enterprises, government bodies that use ICT, in households that are consumers of ICT products and services, and in the environment.

According to the form of manifestation the socio-ecoeconomic effects of the introduction and use of ICT should be divided into direct and indirect ones. Direct socio-eco-economic effects are a direct consequence of the development, production, operation, utilization of ICT equipment or the purpose of the introduction and use of ICT (monitoring and control of natural objects, etc.). Indirect socio-eco-economic effects are not aimed at the introduction of ICT and arise in the process of their use as a side effects (the change

\begin{tabular}{|c|}
\hline Classification of effects from the introduction and use of ICTs \\
\hline $\begin{array}{l}\text { According to the periodicity of calculation: short-term (for a year, a quarter, a month); } \\
\text { mid-term; long-term }\end{array}$ \\
\hline $\begin{array}{l}\text { According to the life cycle of the product: at the stages of development, production, } \\
\text { marketing, consumption, utilization }\end{array}$ \\
\hline According to the form of manifestation: direct, indirect \\
\hline According to the scale: global, national, regional, local \\
\hline According to the direction of influence: positive direction, negative direction \\
\hline $\begin{array}{l}\text { According to the sphere of influence: economic, social, political, environmental, } \\
\text { technological, cultural }\end{array}$ \\
\hline According to the degree of use of ICTs: first-order, second-order, third-order \\
\hline $\begin{array}{l}\text { According to the recipients of influence: the effects that arise in enterprises that use } \\
\text { ICTs, bodies of state power using ICTs, households that are consumers of ICT goods } \\
\text { and services, the environment }\end{array}$ \\
\hline
\end{tabular}

Figure 1. Classification of effects from the introduction and use of ICT

Source: compiled by authors 
in the volume of emissions of harmful substances from transport by changing the volume of passenger and freight due to the introduction of teleworking, e-commerce, etc.).

Consider the economic, social and environmental effects for determination of the socio-eco-economic implications of the introduction and use of ICT.

As it can be seen from Table 1, the benefits of ICT development are the growth of the ICT market, the emergence of new jobs. The development of ICT stimulates investment in research and development in this area; companies are ready to invest as much as possible in ICT implementation. This leads to the emergence of new types of entrepreneurial activities related to the providing of ICT infrastructure and the providing of the necessary services: mobile communications market, fiber optic production, etc.

Application of ICT in business can: reduce costs through automation of management, as well as the properties of virtual ICT goods (low marginal costs for copying, distributing and providing communication); reduce operating costs; increase the efficiency of networks for supply and production; reduce the volume of stocks due to the use of systems "exactly in time"; conducting of Internet conferences, negotiations reduces expenses for business trips. Small and mediumsized enterprises, thanks to the development of e-commerce, have the opportunity to enter on new consumer markets, which previously was only available to large companies.

\subsection{Impact of ICT in the economic, social and environmental spheres}

The development of ICT, in particular the Internet, provides consumers with more opportunities for obtaining information about a products or companies, for organizing communities and movements for consumer rights protection. Due to the fact that online economic relations occur without direct contact between the consumer and the company providing the goods or services, the trust and image of the company is of great importance. Therefore, the development of ICT to some extent contributes to increasing social responsibility in the activities of companies.

The use of ICT is also closely linked to the rapid expansion of world financial markets: ICT facilitate rapid exchange of information, high speeds of realization of financial transactions, and attracting most number of participants, including private investors.

However, there are some problems associated with the development of ICT. A significant problem is the uneven distribution of economic benefits between countries and regions. This is due to the fact that the rapid development of ICT allows developed countries to achieve greater economic growth through the use of ICT, while developing countries have no access to benefits from the introduction of new technologies and are increasingly lagging behind in economic development. At the same time, the very development of ICT can provide an opportunity to "equalize" the economic development of different regions.

Table 1

Influence of ICT in the economic sphere

\begin{tabular}{|c|c|c|}
\hline $\begin{array}{c}\text { First-order effects } \\
\text { (related to the development, production, } \\
\text { operation, utilization of ICT) }\end{array}$ & $\begin{array}{l}\text { Second-order effects } \\
\text { (related to ICT use: e-commerce, etc.) }\end{array}$ & $\begin{array}{l}\text { Third-order effects } \\
\text { (associated with the massive use } \\
\text { of ICT in the long run period) }\end{array}$ \\
\hline $\begin{array}{l}\text { 1. Growth of the ICT market: increasing the } \\
\text { size of the industry and the level } \\
\text { of employment. } \\
\text { 2. Constant investments in ICT: increasing } \\
\text { of investments in ICT, researches and } \\
\text { developments. } \\
\text { 3. The emergence of new types } \\
\text { of entrepreneurial activity: } \\
\text { - Realization of structural changes } \\
\text { in the economy; } \\
\text { - Increasing the risk of bankruptcy as a result } \\
\text { of market volatility. }\end{array}$ & $\begin{array}{l}\text { 1. Application of ICT in business: } \\
\text { - Creating opportunities for new types } \\
\text { of efficiency in business; } \\
\text { - Access to new markets and goods for small } \\
\text { and medium businesses; } \\
\text { - Increasing of costs on proving security } \\
\text { of information systems. } \\
\text { 2. The development of financial markets: } \\
\text { - Increasing the opportunities for the } \\
\text { development of new financial markets and } \\
\text { promoting greater participation in them. } \\
\text { 3. Improving of relations between business } \\
\text { and the market: } \\
\text { - Extension of the consumer rights } \\
\text { and the possibilities of their protection; } \\
\text { - Increasing the social responsibility } \\
\text { of companies as a way of attracting } \\
\text { consumers to e-commerce, etc. }\end{array}$ & $\begin{array}{l}\text { 1. Ensuring sustainable development: } \\
\text { reducing environmental impacts due to } \\
\text { fundamental changes in the global economy } \\
\text { in the long-term period. } \\
\text { 2. Distribution of economic benefits: } \\
\text { - Increasing uneven distribution of } \\
\text { economic benefits due to differences } \\
\text { in the level of use of ICT benefits in different } \\
\text { regions or sectors of the economy; } \\
- \text { Ensuring an even distribution of economic } \\
\text { benefits through ICT }\end{array}$ \\
\hline
\end{tabular}

Source: compiled by authors 
In the social sphere, the development of the ICT industry (production, implementation and use of ICT) contributes to the creation of new jobs and the increasing the need for qualified IT specialists (Table 2). Opportunities for education are expanded: in particular, distance learning helps people with disabilities to receive education without attending regular classes at educational institutions.

With the development of the Internet, access to information about health, medicines expanded, opportunity to receive services in areas of health care (online consultation), public administration (e-government) become available. The Internet can also be used by inhabitants of developing countries to fight for their rights and appeal to international human rights organizations.

Negative aspects of the impact of ICT in the social sphere are related to the security and reliability of information obtained through ICT tools.

In particular, quite often you can find false and unconfirmed information on the Internet, the use of which can sometimes lead to undesirable consequences. A significant problem is the use of the Internet and computer equipment for criminals to commit economic crimes (Internet fraud), the printing of false documents, the spread of child pornography, drug propaganda, and the creation of sites of terrorist organizations. ICT also increase the disparity in access and use of their benefits by representatives of different segments of the population (urban and rural population), countries. This phenomenon is called "digital gap" and it is connected with the fact that people who have broad access to
ICT tend to have more opportunities for higher education, highly paid work and decent living standards. The development of the Internet also has an impact on the dissemination and preservation of cultural values. ICT can contribute to this (to create local community websites on the Internet, to place information on their culture and civilization, etc.) and to provoke a reduction in the diversity of cultures as a result of the wide spread of Western culture (Westernization) and English on the Internet.

ICT can also have an impact on the environment (Table 3).

The development of ICT provides a reduction in the material component of production and consumption, contributing to reducing the resource intensity and ecological sustainability of economic processes, resource conservation, and improving the environmental situation. The advantage of ICT is the improving working conditions, the increasing of the skills of employees, and more. But at the same time, information technology can harm the environment. The production, use and utilization of ICT equipment is becoming a serious environmental problem, since, in particular, computers have a relatively short lead time, their production is accompanied by the use of toxic chemicals, and utilization requires substantial control. That is why in the developed countries of the world a lot of attention is paid to the problem of waste utilization: companies that product computers and other ICT equipment are obliged to adhere strictly to the rules of utilization of electronic equipment in order to prevent environmental pollution.

Table 2

Influence of ICT in the social sphere

\begin{tabular}{|c|c|c|}
\hline $\begin{array}{l}\text { First-order effects (related } \\
\text { to the development, production, } \\
\text { operation, utilization of ICT) }\end{array}$ & $\begin{array}{l}\text { Second-order effects } \\
\text { (related to the ICT use: e-commerce, etc.) }\end{array}$ & $\begin{array}{l}\text { Third-order effects (associated with the } \\
\text { massive use of ICT in the long run period) }\end{array}$ \\
\hline $\begin{array}{l}\text { 1. Changing the level } \\
\text { of employment: } \\
\text { - Creation of new jobs } \\
\text { in the field of ICT; } \\
\text { - Reducing the number of jobs } \\
\text { resulting from the automation } \\
\text { of production processes. } \\
\text { 2. The emergence of a digital } \\
\text { gap: the difference in access } \\
\text { to ICT. }\end{array}$ & $\begin{array}{l}\text { 1. Access to information: } \\
\text { - Availability of the information on the Internet about } \\
\text { health, medicines, etc.; } \\
\text { - Access to information on the Internet in the field } \\
\text { of public administration (e-government); } \\
\text { - Enhancing e-literacy among the rural population. } \\
\text { 2. Safety issues: } \\
\text { - Availability of unconfirmed, inaccurate, false information } \\
\text { on the Internet; } \\
\text { - Use of the Internet and computer equipment for } \\
\text { committing crimes. } \\
\text { 3. Access to services: the possibility of receiving services } \\
\text { in the field of health care, distance learning, public } \\
\text { administration for people with disabilities, etc. } \\
\text { 4. Creating new communities of people on the Internet. } \\
\text { 5. New methods of protest: use of Internet by the } \\
\text { inhabitants of developing countries to appeal to human } \\
\text { rights international organizations to fight for human rights. }\end{array}$ & $\begin{array}{l}\text { 1. Change in cultural diversity: } \\
\text { - Reducing the diversity of cultures } \\
\text { as a result of the spread of Western culture } \\
\text { and English on the Internet; } \\
\text { - Dissemination and preservation } \\
\text { of cultural values through ICT; } \\
\text { - The possibility of "dialogue" between } \\
\text { cultures and civilizations. } \\
\text { 2. Creation of local communities through } \\
\text { ICT. } \\
\text { 3. Enhancing of civic culture: increasing } \\
\text { the participation of citizens in public life } \\
\text { through ICT. }\end{array}$ \\
\hline
\end{tabular}

Source: compiled by authors 
Table 3

Influence of ICT on the environment

\begin{tabular}{|c|c|c|}
\hline $\begin{array}{l}\text { First-order effects (associated with } \\
\text { the development, production, } \\
\text { operation, utilization of ICT) }\end{array}$ & $\begin{array}{c}\text { Second-order effects } \\
\text { (associated with ICT use: e-commerce, etc.) }\end{array}$ & $\begin{array}{l}\text { Third-order effects } \\
\text { (associated with the massive use of } \\
\text { ICT in the long time period) }\end{array}$ \\
\hline $\begin{array}{l}\text { 1. Development and production } \\
\text { of ICT equipment: } \\
\text { - Relatively small workload of ICT } \\
\text { equipment production; } \\
\text { - Use of toxic substances in } \\
\text { production; } \\
\text { - The emergence of new, } \\
\text { energy-efficient ICT. }\end{array}$ & $\begin{array}{l}\text { 1. Reduction of emissions of harmful substances } \\
\text { from transport due to: } \\
\text { - Reduction of passenger traffic as a result } \\
\text { of the proliferation of telework ("at home"); } \\
\text { - Reduction of the number of freight traffic as a result } \\
\text { of logistics application; } \\
\text { - Reducing traffic congestion, reducing travel times through } \\
\text { the use of modern means of communication. } \\
\text { 2. Increase in the emissions of harmful substances } \\
\text { from transport due to: } \\
\text { - An increase in the number of deliveries "home" } \\
\text { with the development of e-commerce due to unoptimized } \\
\text { delivery system. }\end{array}$ & $\begin{array}{l}\text { 1. Separation of processes } \\
\text { of economic growth from increasing } \\
\text { environmental load: the possibilities } \\
\text { of reducing consumption of energy } \\
\text { and emissions of harmful substances } \\
\text { into the environment per unit } \\
\text { of GDP. }\end{array}$ \\
\hline $\begin{array}{l}\text { 2. Exploitation of ICT equipment: } \\
\text { increasing the level of environmental } \\
\text { pollution in the production } \\
\text { of electricity consumed by ICT } \\
\text { equipment, even in standby mode. } \\
\text { 3. Utilization of ICT equipment: } \\
\text { - The problem of utilization of waste } \\
\text { due to rapid moral depreciation } \\
\text { of ICT equipment; } \\
\text { - Increasing the level of recycling } \\
\text { and reuse of waste }\end{array}$ & $\begin{array}{l}\text { - An increasing in the number of travelers due to increased } \\
\text { human mobility through ICT and increased leisure time. } \\
\text { 3. Application of ICT in business: reducing environmental } \\
\text { burden when introducing new business models } \\
\text { of e-commerce, ICT-managed systems. } \\
\text { 4. Virtualization of material products: saving natural } \\
\text { resources by distributing virtual goods (e-books, } \\
\text { e-handbooks, films, music on the Internet). } \\
\text { 5. Effects associated with the life cycle of goods: } \\
\text { - Increasing the life cycle of goods on the market } \\
\text { when using e-commerce models; } \\
\text { - Saving of natural resources due to the reduction } \\
\text { of the terms of development through the use of ICT. } \\
\text { 6. Dissemination and management of information } \\
\text { on the state of the environment: } \\
\text { - Introduction of monitoring of the state } \\
\text { of the environment; } \\
\text { - Use of satellite systems to reduce the negative } \\
\text { consequences of natural disasters; } \\
\text { - Control over the effective use of natural resources; } \\
\text { - Availability of publicly available information on the state } \\
\text { of the environment: climate, biodiversity, etc., } \\
\text { which helps to increase the population's activity } \\
\text { in the field of environmental protection }\end{array}$ & $\begin{array}{l}\text { 2. Changing the principles } \\
\text { of population settlement: } \\
\text { - The possibility of increasing the } \\
\text { compactness of people living in a } \\
\text { certain territory and reducing the } \\
\text { use of natural resources (reducing } \\
\text { the area used for offices, shops, etc. } \\
\text { through the use of the Internet } \\
\text { for work and in everyday life); } \\
\text { - Reverse effect: the possibility } \\
\text { of creating settlements in any } \\
\text { locality, which can lead to increased } \\
\text { environmental load }\end{array}$ \\
\hline
\end{tabular}

Source: compiled by authors

\subsection{The potential of ICT for improving the environment}

However, ICT, on the other hand, has a powerful potential for improving the environment. There are many examples that prove this. The development of communication systems, in particular the Internet, in some cases, for example, eliminates the need to go to work or study daily, which in turn can lead to less frequent use of cars. The development of e-commerce, in particular, making purchases on the Internet, eliminates the need for shopping trips, and, consequently, the use of automotive tools. However, as a result of not optimized deliveries "home" increases the amount of freight. Along with this, ICTs are already used to improve transport, reduce its negative environmental impact. They provide an opportunity to regulate the behavior of drivers: to implement control over traffic flows, to apply flexible tariffs on individual sections of roads, and to differentiate drivers in different categories with the help of "chips". With such electronic systems, traffic flows in cities can be organized more efficiently.

The use of means in information and communication technologies reduces the amount and volume of material products that circulate in various sectors of the economy. One of the most obvious examples is the "e-books" that exist in the form of downloaded electronic files. The result of developing the technology of "e-books" for the publishing industry is a significant reduction in the need for paper, reducing the need for glues and paints, reducing transport costs, etc. 
A similar effect is accompanied by the spread of technologies that use MPEG standards, which makes companies producing audio products able to use CDs for their products. At the same time, virtualization of products should be balanced with the opposite trend of "de-virtualization." This means that the resources required for the production of virtual products (energy, consumables, labor intensity, etc.) should not exceed the corresponding total resources necessary for the production of material products. (European Information Technology Observatory yearbook, 2002)

ICT provide producers with effective means to quickly and accurately meet the existing needs of society by globally expanding the search potential of potential consumers and producing larger volumes of products. At the same time, they have the opportunity to reduce their losses caused by the reduction in the life cycle of goods (E-government and the business environment. The impact of ICT on sustainable development, 2002). The use of ICT for a long period of time may lead to changes in the principles of resettlement: using the Internet for work and in everyday life allows you to reduce the area used for offices, shops, etc., thereby making people more compact in the area and reducing the use of natural resources. At the same time, using the Internet to work and in everyday life allows an individual to create settlements in any area where access to the Internet is available, which may lead to an increase in the use of natural resources. The implementation of ICT allows to receive more information on such phenomena as climate change, biodiversity and helps explore natural conditions for the timely application of environmental protection measures. For example, sensors connected to a computer system, allow you to capture the leakage of a particular resource and optimize production processes from the point of view of resource efficiency. There are systems in the world that disseminate information on common issues (Creating a Development Dynamic, 2001) such as climate change, biodiversity, marine and coastal management, and energy resources.
The processes of the development, production, operation and utilization of ICT equipment have a negative impact on the environment. Most fields of ICT applications, such as e-commerce, e-government, e-banking, etc., increase not only the efficiency of the use of natural resources but also can affect the change in the use of transport, and hence the emission of harmful substances into the air.

\section{Conclusions}

The use of ICT promotes increasing of work productivity in many areas of the national economy but their implementation requires significant capital investment. In the social sphere, ICTs provide extensive opportunities for learning, promote the participation of citizens in public life, etc., but at the same time they can increase the unevenness of the economic development of the regions of the country due to the difference in access to ICT. Negative effects are more related to the availability of ICT (production, operation and utilization of ICT equipment), and the positive effects with using of ICT. The development of ICT provides a reduction in the material component of production and consumption, helping reduce the resource intensity and ecological sustainability of economic processes and improve the environmental situation.

Based on the study and systematization of socio-ecoeconomic effects from the introduction and use of ICT, the classification features and classification of effects are presented, namely: according to the product life cycle - the effects that arise at the stage of development, production, sale, consumption and utilization of the product; according to recipients of influence - the effects arising from enterprises, government bodies that use ICT, households that are consumers of ICT goods and services, and in the environment; according to the form of manifestation - direct and indirect effects. The conducted analysis and systematization of the effects of the introduction and use of ICT can be used as a basis for the formation of scientific and methodological approaches to the social-ecologicaleconomic substantiation of the implementation of ICT.

\section{References:}

Balatskiy, O. F. (1979). Ekonomika chistogo vozdukha [The economy of clean air]. Kyiv: Naukova dumka. (in Russian)

Zgurovskiy, M. Z. (2005). Put k informatsionnomu obshchestvu - ot Zhenevy do Tunisa [The way to the information society - from Geneva to Tunisia]. Zerkalo nedeli, vol. 34. Available at: http://www.compete.org.ua/. (in Russian)

Inozemtsev, V. L. (2000). Sovremennoye postindustrialnoye obshchestvo: priroda, protivorechiya, perspektivy [Modern post-industrial society: nature, contradictions, perspectives]: Manual for students of higher schools. Moscow: Logos. (in Russian)

Ivanova, V. V. (2008). Rol informatsiinoho rynku $\mathrm{v}$ transformatsiinykh protsesakh ekonomiky [The role of the information market in the transformational processes of the economy]. Ekonomiko-matematychne modeliuvannia sotsialno-ekonomichnykh system [Economic and mathematical modeling of socio-economic systems], vol. 13, pp. 16-24. (in Ukrainian) 
Castells, M., Hymanen, P. (2002). Informatsionnoye obshchestvo i gosudarstvo blagosostoyaniya: Finskaya model [Information society and the state of welfare: The Finnish model]. Moscow: Logos. (in Russian)

Kovalevskyi, V. O. (2003). Teoretyko-metodolohichni zasady informatsiinoho suspilstva [Theoretical and methodological foundations of the information society]. Available at: http://kovalevsky.webs.com.ua/theory/ theory.htm. (in Ukrainian)

Lyon, D. (1996). Informatsiine suspilstvo: problemy ta iliuzii. Informatsiia, ideolohiia ta utopiia [Informational society: problems and illusions. Information, ideology and utopia]. Suchasna zarubizhna sotsialna filosofiia. Kyiv. Available at: http://www.philsci.univ.kiev.ua/biblio/lajon.html. (in Ukrainian)

Makarova, M. V. (2002). Elektronna komertsiia [E-commerce]. Kyiv: Academy. (in Ukrainian)

Rol sovremennykh informatsionnykh tekhnologiy $\mathrm{v}$ sotsialno-ekonomicheskom razvitii [The role of modern information technologies in socio-economic development] (2005). Microsoft Newsletter, vol. 29. Available at: http://microsoft.com/rus/. (in Russian)

Khlobystov, Ye. V. (2004). Ekolohichna bezpeka transformatsiynoi ekonomiky [Ecological security of the transformational economy]. Kyiv: Chornobylinterinform. (in Ukrainian)

Chukhno, A. A. (2003). Postindustrialna ekonomika: teoriia, praktyka ta yikh znachennia dlia Ukrainy [Postindustrial economics: theory, practice and their significance for Ukraine]. Kyiv: Logos. (in Ukrainian)

Creating a Development Dynamic (2001). Final Report of the Digital Opportunity Initiative. Accenture. Markle Foundation, United Nations Development Programme.

E-government and the business environment. The impact of ICT on sustainable development (2002). European Information Technology Observatory, pp. 250-285.

European Information Technology Observatory yearbook (2002). European Information Technology Observatory. Nelson, C. A. (1993). International Business: A Manager's Guide to Strategy in the Age of Globalism.

Varakin, L. E. (2005). Digital Divide in the Global Information Society. The Theory and Practice of Measurement: 3-rd ed., prepared specially for the World Summit on the Information Society (Tunis, 2005). Moscow: ITA. 